\title{
Methodology for Determining Increases in Radionuclide Inventories for the Effluent Treatment Facility Process
}

by

A. Blanchard

Westinghouse Savannah River Company

Savannah River Site

Aiken, South Carolina 29808

M. A. Nadeau

1. Palk

c. Kuhn

This paper was prepared in connection with work done under the above contract number with the U.S. Department of Energy. By acceptance of this paper, the publisher and/or recipient acknowledges the U.S. Government's right to retain a nonexclusive, royalty-free license in and to any copyright covering this paper, along with the right to reproduce and to authorize others to reproduce all or part of the copyrighted paper. 


\section{DISCLAIMER}

This report was prepared as an account of work sponsored by an agency of the United States Government. Neither the United States Government nor any agency thereof, nor any of their employees, makes any warranty, express or implied, or assumes any legal liability or responsibility for the accuracy, completeness, or usefulness of any information, apparatus, product, or process disclosed, or represents that its use would not infringe privately owned rights. Reference herein to any specific commercial product, process, or service by trade name, trademark, manufacturer, or otherwise does not necessarily constitute or imply its endorsement, recommendation, or favoring by the United States Government or any agency thereof. The views and opinions of authors expressed herein do.not necessarily state or reflect those of the United States Government or any agency thereof.

This report has been reproduced directly. from the best available copy.

Available to DOE and DOE contractors from the Office of Scientific and Technical Information, P. O. Box 62, Oak Ridge, IN 37831; prices available from (423) 576-8401.

Available to the public from the National Technical Information Service, U. S. Department of Commerce, 5285. Port Royal Road, Springfield, VA 22161. 


\section{DISCLAIMER}

Portions of this document may be illegible in electronic image products. Images are produced from the best available original document. 
WSRC-TR-98-00257

Revision 0

\section{METHODOLOGY FOR DETERMINING INCREASES IN RADIONUCLIDE INVENTORIES FOR THE EFFLUENT TREATMENT FACILITY PROCESS}

JULY 1998

Westinghouse Savannah River Company Aikon, SC 29808

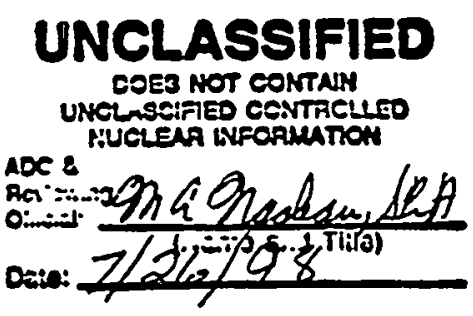

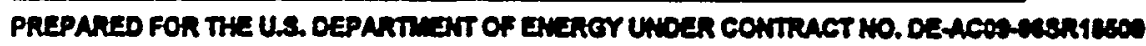

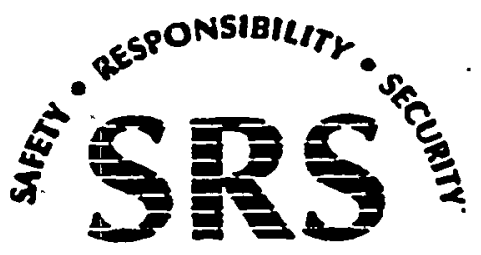

SAVANNAH RIVER SITE 


\section{METHODOLOGY FOR DETERMINING INCREASES IN RADIONUCLIDE INVENTORIES FOR THE EFFLUENT TREATMENT FACILITY PROCESS}

JULY 1998

Westinghouse Savannah Rlver Company Aikøn, SC 29808

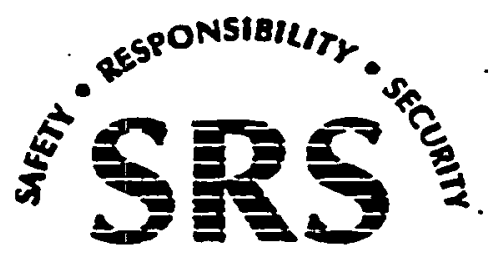

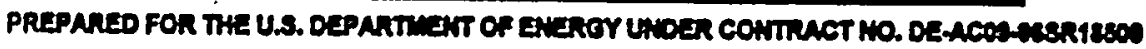


WSRC-TR-98-00257

Revision 0

Project: Methodology for Determining Increases in Radionuclide Inventories for the Effluent Treatment Facility Process

Document:

Tịtle:
WSRC-TR-98-00257, Revision 0

Methodology for Determining Increases in Radionuclide Inventories for the Effluent Treatment Facility Process

Approvals:

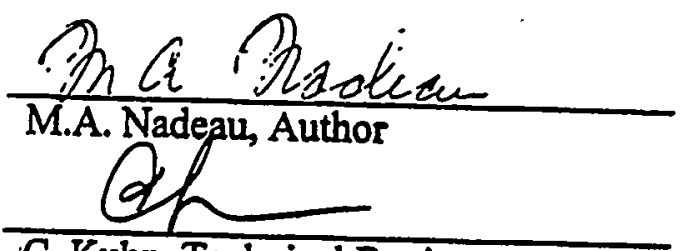

C. Kuhn, Technical Reviewer

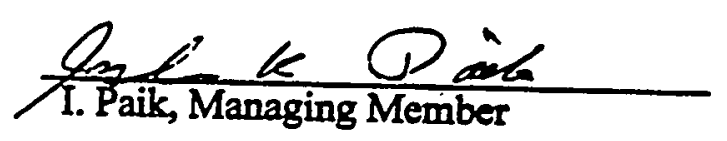

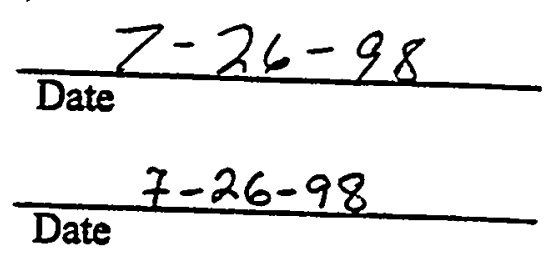

Date $7-27-98$ 


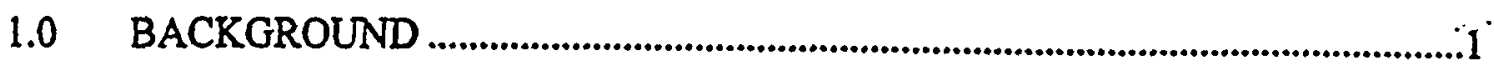

2.0 DISCUSSION

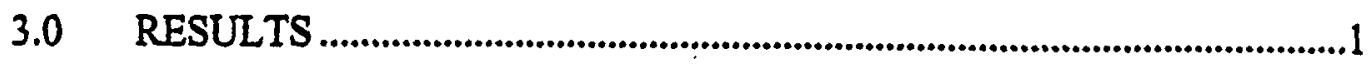

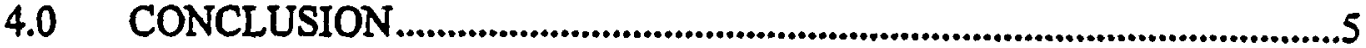

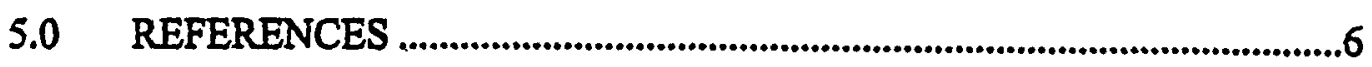


This page intentionally left blank. 


\subsection{BACKGROUND}

A study is currently underway to determine if the Effluent Treatment Facility (ETF) can be downgraded from a Hazard Category 3 facility to a Radiological Facility per DOE STD-1027-92 (Ref. 1). From the DOE review of Revision 0 of the Hazard Baseline Downgrade Effluent Treatment Facility (Ref. 2), one comment remains unresolved. The DOE has requested that a better basis be provided to determine the size of process column radionuclide inventory increases in the ETF over time. This technical report provides a methodology to determine and monitor increases in the radionuclide inventories of the ETF process columns. It also provides guidelines to ensure that other potential increases to the ETF radionuclide inventory are evaluated as required to ensure that the ETF remains a Radiological Facility.

\subsection{DISCUSSION}

The Hazard Baseline Downgrade, Rev. 1, will redefine the facility Segments. The F-Area Cooling Water Basins, the H-Area Cooling Water Basins, and each of the retention basins are defined as separate segments. Segments 5 and 6 will be defined as described below.

Segment 5 includes the Lift Stations, Force Main, the Wastewater Collection Tanks, and a chemical storage area. The Mercury Removal and Carbon Absorption Columns for the Organic Removal System are located near the Wastewater Collection Tanks. Segment 6 includes the Treatment Building, Control Building, Outside Tanks and the HEPA filters. Cation Columns and Mercury Removal Columns are located in the Treatment Building. The two sets of mercury removal columns, the carbon columns, and the cation columns comprise the process columns for this facility.

Westinghouse Safety Management Solutions personnel worked with representatives of Solid Waste Regulatory Programs and Solid Waste Engineering to determine an appropriate method of determining potential increases in the radionuclide inventory held in the columns. The method developed is required to ensure that increases in column inventory do not raise the inventory of any segment above the Category 3 threshold limit values from Reference 1 . Increases of inventory to the basins and from temporary sources have also been considered.

\subsection{RESULTS}

A baseline value must be determined for the Columns in Segments 5 and 6 . The radionuclide inventory of the incoming Waste Water and exiting Waste Concentrate will . be conservatively determined for gross alpha and gross beta-gamma. If separate samples results are available for Cesium 137, separate calculations may be made for this radionuclide. To take this option, Cesium 137 sample result must be available for both Waste Water and the Waste Concentrate. 
Before the contents of a waste water collection tank are processed, it is agitated and sampled. The sample results for gross alpha and gross beta-gamma are given with an error band. Sample results are provided in $\mathrm{d} / \mathrm{min} / \mathrm{ml}$. The value that is used in the calculations will be the maximum value in the error band. The product of this value and the volume of water to be processed will be used to find the maximum value for the inventory to be processed. The volume of the water in the Waste Water collection tank will be given in gallons. References 3 and 4 supplied conversion factors.

$A_{W W}=\mathrm{d} / \mathrm{min} / \mathrm{ml}$ of alpha radiation in Waste Water

$\mathrm{BG}_{\mathrm{WW}}=\mathrm{d} / \mathrm{min} / \mathrm{ml}$ of beta gamma radiation in Waste Water

$\mathrm{Cs} 137_{\mathrm{WW}}=\mathrm{d} / \mathrm{min} / \mathrm{ml}$ of Cesium 137 in Waste Water (optional calculation)

$\mathrm{V}_{\mathrm{WW}}=$ volume of Waste Water in gallons

$I=$ incoming inventory in curies

$I($ alpha $)=A_{W W} d / \mathrm{min} / \mathrm{ml} * V_{W W}$ gal $* 3785 \mathrm{ml} / \mathrm{gal} * \mathrm{Ci} / 3.71 \mathrm{E} 10 \mathrm{~d} / \mathrm{s} * \mathrm{~d} / \mathrm{s} / 60 \mathrm{~d} / \mathrm{min}$

$I$ (beta/gamma) $=B G_{W w} \mathrm{~d} / \mathrm{min} / \mathrm{ml} * \mathrm{~V}_{W w} \mathrm{gal} * 3785 \mathrm{ml} / \mathrm{gal} * \mathrm{Ci} / 3.71 \mathrm{E} 10 \mathrm{~d} / \mathrm{s} * \mathrm{~d} / \mathrm{s} / 60 \mathrm{~d} / \mathrm{min}$

$I(C s 137)=C s 137_{\text {WW }} \mathrm{d} / \mathrm{min} / \mathrm{ml} * V_{W W} \mathrm{gal} * 3785 \mathrm{ml} / \mathrm{gal} * \mathrm{Ci} / 3.71 \mathrm{E} 10 \mathrm{~d} / \mathrm{s} * \mathrm{~d} / \mathrm{s} / 60 \mathrm{~d} / \mathrm{min}$

The waste concentrate is also sampled. Again the values for gross alpha and gross betagamma will be taken. The minimum value within the error band will be selected and the product of this value and the volume of waste concentrate will determine the minimum radionuclide inventory that leaves the ETF. Conservatively, the inventory of the Treated Water Tanks is not considered. However, the non-tritium radionuclide inventory of the Treated Water Tanks is low and will not significantly lower the calculated hold up in the facility (Ref.5).

$A_{\text {WC }}=\mathrm{d} / \mathrm{min} / \mathrm{ml}$ of alpha radiation in Waste Concentrate

$B G_{\text {WC }}=\mathrm{d} / \mathrm{min} / \mathrm{ml}$ of beta gamma radiation in Waste Concentrate

Cs137 $7_{\mathrm{WC}}=\mathrm{d} / \mathrm{min} / \mathrm{ml}$ of Cesium 137 in Waste Concentrate (optional calculation)

$\mathrm{V}_{\text {WC }}=$ volume of Waste Concentrate in gallons

$E=$ Waste $\cdot$ Concentrate exiting inventory in curies.

$E($ alpha $)=A_{W C} d / \mathrm{min} / \mathrm{ml} * V_{W C} g a l * 3785 \mathrm{ml} / \mathrm{gal} * \mathrm{Ci} / 3.71 \mathrm{E} 10 \mathrm{~d} / \mathrm{s} * \mathrm{~d} / \mathrm{s} / 60 \mathrm{~d} / \mathrm{min}$

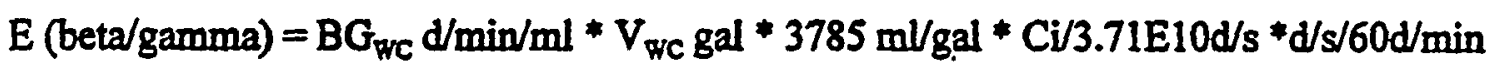

$E(C s 137)=C s 137_{W C} d / \min * V_{W C} g a l * 3785 \mathrm{ml} / \mathrm{gal} * C i / 3.71 E 10 d / s * d / s / 60 d / m i n$

The difference between the incoming radionuclide inventory and the radionuclide inventory exiting the facility in the waste concentrate will typically provide the maximum . available inventory for hold up on the ETF process columns and elsewhere in the facility. Occasionally additional inventory is added to the process downstream of the Waste Water 
Collection Tanks. Typically this material is delivered in tank trucks. This material is also considered in determining maximum available inventory for hold up.

$D=$ total inventory potentially available for holdup (for tritium, $D=0$ )

$A_{T T}=\mathrm{d} / \mathrm{min} / \mathrm{ml}$ of alpha radiation added to process downstream of WWCT

$B G_{\pi T}=\mathrm{d} / \mathrm{min} / \mathrm{ml}$ of beta gamma radiation added to process downstream of WWCT

Cs137 $1 \pi=\mathrm{d} / \mathrm{min} / \mathrm{ml}$ of Cesium 137 added to process downstream of WWCT

$D($ alpha $)=I$ (alpha) $+A_{\pi}-E$ (alpha)

$D\left(\right.$ beta/gamma) $=I$ (beta/gamma) $+B G_{T T}-E$ (beta/gamma)

$D(C s 137)=I(C s 137)+C s 137_{\pi}-E(C s 137)$

Gross alpha and gross beta gamma will be used in the calculation. Tritium inventory will be neglected for holdup. Tritium inventory is assumed to be constant in the facility. It is not removed by processes in the ETF (Ref. 6 ).

Two running totals must be maintained for the radionuclide inventory that potentially remains in Segments 5 and 6 of the facility. Calculations for Segment 6 will follow the same methodology as those for Segment 5 . Clearly the use of maximum possible inventory for the incoming radionuclides and minimum possible inventory for the exiting radionuclides will provide an overestimate of the amount of inventory retained on the columns and elsewhere in the facility. Also, some small amount of inventory will also be released with the treated water. Each total will include the amount potentially retained in the columns and else where in the facility added to the other inventory for that segment shown in the Hazard Baseline Downgrade and any other radionuclide inventory that may be in the segment. When the potential retained inventory along with the other inventory for Segments 5 or 6 reaches $95 \%$ of the threshold limit value for a Category 3 facility, a new evaluation must be performed to ascertain the inventory that is held in the columns and elsewhere in that segment.

$R_{s}=$ radionuclide inventory in Segment 5 other than hold up inventory - as shown in the Hazard Baseline Downgrade

$B_{s}=$ baseline hold up inventory for Segment 5

$A_{s}=$ any other additional radionuclide inventory located in Segment 5

$T_{3}=$ total radionuclide inventory in Segment 5

$T_{s}$ (alpha) $=D$ (alpha) $+R_{s}$ (alpha) $+B_{s}$ (alpha) $+A_{s}$ (alpha)

$T_{s}$ (beta/gamma) $=D$ (beta/gamma) $R_{s}$ (beta/gamma) $+B_{s}$ (beta/gamma) $+A_{s}$ (beta/gamma)

$T_{s}(C s 137)=D(C s 137)+R_{s}(C s 137)+B_{5}(C s 137)+A_{s}(\operatorname{Cs} 137)$

$T_{5}(H 3)=R_{5}(H 3)+B_{5}(H 3)+A_{5}(H 3)$ 
In order to compare to the threshold limit values for Category 3 threshold limit values are selected from Reference 1. The Beta-Gamma threshold limit is assumed to be the threshold for Ruthenium 106. The Alpha threshold limit is assumed to be the threshold for Americium 241. These values are judged to bound equivalent threshold limits for expected inventory constituents. Americium 241 was also selected because Americium . composes a significant portion of the inventories expected to be held in the columns (Ref. 6). The sum of the fractions method used below is taken from Reference 1.

$P_{5}=\%$ of Category 3 threshold limit value in Segment 5

$\mathrm{P}_{s}=100 * \mathrm{~T}_{s}($ alpha $) / 5.2 \mathrm{E}-1 \mathrm{Ci}+\mathrm{T}_{s}$ (beta/gamma)/1.0E2 Ci $+\mathrm{T}_{s}(\mathrm{Cs} 137) / 6.0 \mathrm{El} \mathrm{Ci}+\mathrm{T}_{s}$ $(\mathrm{H} 3) / 1.6 \mathrm{E} 4 \mathrm{Ci}]$

$$
\leq 95 \%
$$

Per technical discussions between WSMS and ETF facility engineering, when the sum of the fractions approaches $95 \%$, a new.evaluation must be performed to determine the inventory that is held in the columns and elsewhere in that segment. The evaluation will be performed by ETF engineering. The evaluation may be based on sample results, published studies, and process knowledge. The evaluation will be documented in a calculation note.

The results of the evaluation will be used to determine a new baseline inventory for the hold up in that segment. The decision to change out or clean the columns may be made based on the estimated time for the segment to reach $95 \%$ of the Category 3 threshold limits. A new running total will be initiated using the new hold up inventory baseline. The use of this method to monitor the process will ensure that increases in hold up inventory do not cause the segment to exceed the Category 3 threshold limit values from Reference 1.

It is recognized that there may be build-up of sludge in the basins and that the sludge may contain a concentration of radionuclides greater than that in the basin water. The calculations used to estimate the basin inventory already assume an inventory higher than that permitted by the WAC (Ref. 2). Furthermore, the presence of water over the sludge reduces the source reduction factor for a release.

The facility is required to sample the sludge at any time that the facility engineering judges that the total inventory of the basin may be approaching the Hazard Category threshold limits. An evaluation to determine if sampling is required must be made on at least a yearly basis. The yearly frequency appears to be adequate and supported by the attached analysis of the basin sludge (Ref. 7). This analysis of sludge being removed from the H-Area Retention Basin indicates that the yearly accumulation of radionuclides . is approximately the following:
Alpha
2.00E-03Ci 
WSRC-TR-98-00257

Revision 0

Beta 5.37E-02Ci

Gamma 5.12E-02Ci (Ref. 7, attached)

Comparing to the Hazard Category 3 Threshold limits,

$$
\begin{array}{ll}
\text { Alpha } & 2.00 \mathrm{E}-03 \mathrm{Ci} / 5.2 \mathrm{E}-01 \mathrm{Ci}=3.8 \mathrm{E}-03 \\
\text { Beta/Gamma } & (5.37 \mathrm{E}-02 \mathrm{Ci}+5.12 \mathrm{E}-02 \mathrm{Ci}) / 1.0 \mathrm{E}+02=1.0 \mathrm{E}-03
\end{array}
$$

The sum of the fractions for a one-year accumulation is the following:

$$
3.8 \mathrm{E}-03+1.0 \mathrm{E}-03=4.8 \mathrm{E}-03 \text { threshold limits }
$$

This represents a very small fraction of the Hazard Category 3 threshold limits. At this rate of accumulation, the sludge would not reach the threshold limits for 200 years.

$200 \mathrm{yr} * 4.8 \mathrm{E}-03$ threshold limits/yr $<1$ threshold limit

Also, an evaluation of the radionuclide content of the sludge must be performed before the water level is lowered, potentially exposing the sludge.

As mentioned in the calculation of hold up inventories, other temporary sources of radionuclide inventory may be present in the facility, such as tank trucks. Before the temporary sources may enter the area, the total inventory of the affected segment must be calculated by procedure to ensure that the inventory of the facility remains less than the Hazard Category 3 threshold limits.

\subsection{CONCLUSION}

The level of increase in the radionuclide inventory of the ETF process columns can be effectively controlled. The methodology developed to control the process column and other hold up inventory must be captured in facility procedures. Facility procedures must also control other potential radionuclide inventory increases such as basin sludge and temporary sources. Because these Administrative Controls are necessary to maintain the ETF as a Radiological Facility, they will be prescribed in the facility HASP/ASA. 


\subsection{REFERENCES}

1. Hazard Categorization and Accident Analysis Techniques for Compliance with DOE Order 5480.23, Nuclear Safety Analysis Reports. DOE-STD-1027-92, Change Notice 1, U.S. Department of Energy, Washington, DC, September 1997. . .

2. Nadeau, M.A. Hazard Baseline Downgrade Effluent Treatment Facility (U). WSRC-TR-98-0092, Westinghouse Savannah River Company, Aiken, SC, July 3. Lamarsh, J. R. Introduction to Nuclear Engineering. Addison-Wesley Publishing
Co., Inc., Reading, MA, December 1997.

4. CRC Standard Mathematical Tables. 17th Ed., Chemical Rubber Co. Cleveland,

5. Watkins, R.W. Effluent Treatment Facility Radionuclide Inventory. SWD-ETF98-017, Rev. 1, Westinghouse Savannah River Company, Aiken SC, July 21, 1998.

6. ETF Facility Systems Overview (U). WETIS003, Rev.0, Westinghouse Savannah River Company, Aiken, SC, August 13, 1995.

7. Watkins, R. W. 281-8H H-Area Retention Basin Radionuclide Inventory. SWDETF-98-057, Westinghouse Savannah River Company, Aiken SC, July 22, 1998 (attached). 


\section{WESTINGHOUSE SAVANNAH RIVER COMPANY INTEROFFICE MEMORANDUM}

TO:

M. A. NADEAU, CCC-3

FROM:

R. W. WATKNS, 241-168H

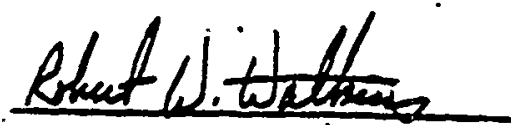

Reviewed by: A. W. Wiggins

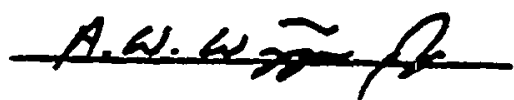

\section{1-BH H-AREA RETENTION BASIN RADIONUCLIDE INVENTORY}

Periodically, because of sediment build-up, the 281-8H H-Area Retention Brsin requires cleaning out. Currently the sediment is being removed from the basin floor to suppost the relining project. Six years have past since the last clean out was done in the fall of 1992 . The extimated amount of sediment to be removed is 100 yd ${ }^{3}$. To date, 5 B-12 boxes have been rewoved which account for spproximately $10 \%$ of the toul cotimated besin solid volurae.

Basin Sedimeat samples were taken on 1029/97 and a rediologieal screening was performed. The bighest alpha, beth, and gamma semple results were used to cormpile Table 1 below.

Table 1

\begin{tabular}{|c|c|c|c|c|}
\hline & $\mathrm{pCi} / \mathrm{s}$ & $\mathrm{Ci} / \mathrm{s}$ & $\begin{array}{l}\text { Estimated Basin } \\
\text { Ci Content }\end{array}$ & $\begin{array}{l}\text { Estimnted CI } \\
\text { Accumulation } \\
\text { per Yeer }\end{array}$ \\
\hline Alphes & 39.27 & 3.93EनII & $1.20 \mathrm{E}-02$ & $2.00 \mathrm{E}-03$ \\
\hline $\operatorname{Bet}$ & 1590.62 & T.59E $=09$ & $3.22 \mathrm{E}-01$ & $3.37 \mathrm{E}-02$ \\
\hline Ganmen & $1 5 \longdiv { 4 . 6 9 }$ & 1.321509 & $3.07 \mathrm{E}-0 \mathrm{I}$ & $5.12 \mathrm{E}-02$ \\
\hline
\end{tabular}

cc: H. A. MCGovem, 241-246H

C. W. McVay, 704-43H

A. W. Wiggins, 241-246H

ETF Correspondeace File, 241-246H

References:

(1) Merno from S. A. Walliser to A. W. Wiggins, HRB Sample Results April 2, 1998, SWD-ETF-98-026.

(2) Memo from S. A. Walliser to A. W. Wigeins, HRB Sediment TCLP Met!Lenits April 15, 1998, SWD-ETF-98-034.

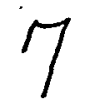

